\title{
Transregionalism and the Caribbean Higher Educational Space
}

Tavis D. Jules

Loyola University Chicago, tjules@luc.edu

Follow this and additional works at: https://ecommons.luc.edu/education_facpubs

Part of the Education Commons

\section{Author Manuscript}

This is a pre-publication author manuscript of the final, published article.

\section{Recommended Citation}

Jules, Tavis D.. Transregionalism and the Caribbean Higher Educational Space. Global Regionalisms and Higher Education: Projects, Processes and Politics, , : 211-227, 2016. Retrieved from Loyola eCommons, Education: School of Education Faculty Publications and Other Works,

This Book Chapter is brought to you for free and open access by the Faculty Publications and Other Works by Department at Loyola eCommons. It has been accepted for inclusion in Education: School of Education Faculty Publications and Other Works by an authorized administrator of Loyola eCommons. For more information, please contact ecommons@luc.edu. c) $($ () $\ominus$

This work is licensed under a Creative Commons Attribution-Noncommercial-No Derivative Works 3.0 License. (c) Edward Elgar Publishing, 2016. 
Transregionalism and the Caribbean higher educational space

\section{Tavis D. Jules}

\section{INTRODUCTION}

This chapter sets out to survey the origins and consequences of the shift of a regional governance mechanism from an 'immature' to a 'mature' form of regionalism, and reflect on its influence on the coordination of activities of higher education across the Caribbean Community (CARICOM) ${ }^{1}$ leading to what can be referred to as 'transregionalism' ${ }^{2}$. The central argument in this chapter is that: (I) the absence of supra-nationality within CARICOM's governance structure led to what is referred to as a form of 'immature regionalism', where decisions made at the regional level were not necessarily implemented at the member state level; and that (2) what is referred to as 'mature regionalism' has emerged as a governance mechanism aimed at ensuring that regional decisions are implemented at the national level. In essence, the criterion of the 'maturity' of the regionalism is the degree to which policy decisions agreed upon at by Heads of Government, the highest decision making body, or by other institutions of CARICOM will be operationalized into the domestic laws of member states across the region.

As a result, rather than such collective decisions having to be approved separately by all members, they will 'have the force of law throughout the region'. It seems clear that the model for 'mature' regionalism is the EU, where Community rules cannot be overturned or ignored at the member state level. As the Lewis Report, 'Managing Mature Regionalism', put it:

Consistent with proposals to improve the effectiveness of Caribbean integration institutions based on relevant EU [European Union] experiences, it is proposed that the system of Community Law already recognised in the provisions of the Revised Treaty of Chaguaramas, should be amplified to cater for the continuous creation of Community Law through the organs and institutions of the Caribbean Community. This should be achieved through the instrumentality of collaboration between the Conference of the Heads of Government and Ministerial Councils (including the Legal Affairs Committee) on the one hand and the Commission on the other. (Lewis, 2006: 6)

Following from this, in this chapter I argue that the Caribbean higher educational space (CHES) can be seen as a form of transregionalism, which will be taken as representing a particular way of conceptualizing the different forms of coordination of regional governance mechanisms or its 'metagovernance' (Jessop, 2000, 2004). Here I make a distinction between governance mechanisms, the coordinating of complex organizations, and system and governance activities - that is the funding, provision, ownership and regulation of education (Dale, 2005). In this context, transregionalism represents the shared 'space between and across regions in which its constituent parts (individuals, communities and organizations) operate [sic]' (Dent, 2003: 224). Metagovernance is seen, not as mode of governance, but rather a way of explicating the forming of self-organization that is reshaping the framework within which collaboration and social learning are developed and coordinated (Jessop, 2004).

In the Caribbean context, metagovernance is a functional concept to explain the 'coordination of relations of complex interdependence' (Jessop, 2004: 62) within shared spaces between and across the Caribbean region. Metagovernance is particularly applicable to CARICOM since it respects the principles of sovereignty (which speaks to its intergovernmentalist nature) and 'collibration' (which includes modes of cooperation and is a feature of its neofunctionalism character), both of which are core defining features of the conceptual pillars of Caribbean integration. In other words, the focus here is on the modes of coordination of independent activities across different territorial scales (above and below the national level) and the functional domains of governance. 
This chapter is developed as follows. First, I review the origins of mature regionalism through an account of the changing nature and expectations around the role of higher education across the different waves of Caribbean regionalism (old regionalism, open regionalism and mature regionalism). Second, I use the concepts of strategic coordination and metagovernance (also known as meta-steering); that is, the 'use of higher- order mechanisms to collibrate different modes of governance (markets, states and other forms of imperative coordination, networks)' (Jessop, 2000: 345) to describe how different modes of non-economic or functional spaces (education, health, transportation, and telecommunications) of Caribbean integration are coordinated across functional and territorial divides by the process of functional cooperation. ${ }^{3}$ Here, mature regional- ism is seen as an example of a higher-order mechanism of governance and it is suggested that transregionalism - the use of horizontal models of governance represents a particular conceptual approach to study how governance mechanisms steer different modes of coordination. Implicit in this framework is that tertiary educational institutions are now an integral part of the political project of regionalism in the Caribbean Single Market. Third, I consider three broad scenarios that are changing Caribbean integration in an era that has come to symbolize the retreat, by nation-states, towards regional trading agreements (RTAs) as the pausing of globalization occurs, or what has been called the 'gated global' (The Economist, 2013). Finally, I explain the role of institutions in regionalism and function of regionalization in steering the higher education agenda. This is done by suggesting that the CHES, a pluri-scalar borderless educational space, is being transformed to conform with the expectations of mature regionalism as educational governance activities have been moved out of the national realm into the regional jurisdiction. Although state sovereignty is pre- served in theory, in practice governance activities are coordinated region- ally. I conclude the chapter by suggesting future discussions around the maturing of regionalism within the context of the free movement regime.

\section{ORIGINS AND SHIFTING GEOMETRY}

It was the Grand Anse Declaration (CARICOM, 1989) that laid the foundation of the regional integration process. In Article 45 of the Revised Treaty of Chaguaramas it is stipulated that 'Member States commit themselves to the goal of the free movement of their nationals within the Community' (CARICOM, 2001: 27). Here I briefly describe how the CHES is being shaped by strategies aimed at developing forms of coordination that are in turn challenging the hold of nationalist tendencies in governing activity.

Within the new geometries that functional spaces now occupy within the Caribbean, 'new scales emerge and/or existing scales gain in institutional thickness, new mechanisms to link or coordinate them also tend to emerge. This in turn often prompts efforts to coordinate these new coordination mechanisms' (Jessop, 2000: 342). As globalization reorders and protection- ism rises, within education 'different actors look[ing] for the best means of inserting themselves into the spatial, scalar and temporal divisions of labour' (Jessop, 2000: 342) giving rise to different institutional dynamics, and governance and regulatory mechanisms across different scalar levels.

Although a few institutions of higher education were founded in the 1800s in places such as Belize and Jamaica, the turn of the century saw an influx of educational opportunities within CARICOM due to investment in education. The regional university, the University of the West Indies (UWI; formerly the University College of the West Indies), was established in 1948 with its first campus in Jamaica (Mona) and other campuses m Trinidad (St Augustine) in 1960, Barbados (Cave Hill) in 1963, and the Open Campus in 2008, under Article 22 of the Revised Treaty of Chaguaramas. The UWI is designated as an Associate Institution of CARICOM that 'enjoys important functional relationships which contribute to the achievement of the objectives of the Community... and such other entities as may be designated by the Conference' (CARICOM, 2001: 15).

The Caribbean Examination Council (CXC), established in 1972, is also recognized as an Institution of CARICOM under Article 21 of the Revised Treaty. At the beginning of the new millennium, CXC was tasked with administering 
the Caribbean Vocational Qualification (CVQ). The CVQ assesses the competency of occupational standards created by the practitioners, field experts, and employers. Further, the standards allow for the portability of national credentials across nations based on the tiered levels of certification mastery. As formal institutions of CARICOM, the UWI and CXC are functional entities with responsibilities for creating policies and performing functions in relation to cooperation, and hence are responsible for the metagovernance of what can be described as mature regionalism. However, in an era defined by the ability of Caribbean nationals with the necessary qualification to move under the auspices of the new skills regime, the landscape of higher education now consists of close to 100 accredited private and public, two-year and four-year, and specialty institutions which now operate regionally.

As the charter of regionalism has changed, so too has its nodal scale, thus engendering the relativization of scale across different regionalisms where old scales are reordered or broken down and new ones emerge through different mechanism of governance, giving rise to mature regionalism. One outcome is that new institutions are developed and are envisioned to work alongside old institutions. In 1967, Sir Philip Sherlock, the second Vice-Chancellor of the UWI, believed that 'educational cooperation' was the instrument to be used to foster regional awareness (Parkins, 2007). The notion of regional cooperation was widely accepted in the region, and the Association of Caribbean Universities and Research Institutes (UNICA) was founded in 1967 to foster cooperation among the Higher Education Centres in the Caribbean Region.

UNICA was unique in that it encompassed all nations touched by the Caribbean Sea, regardless of cultural and national differences. Prior to the establishment of UNICA, only a select number of individuals were able to create connections with their counterparts in other nations. The association helped to redefine relationships between nations, and offered more intentional opportunities to network across borders, in turn creating opportunities for institutions to have an impact on the economic, social and cultural development of nations of the Caribbean.

New challenges have arisen as UNICA and education provision in the Caribbean have grown. Most notably, the globalization of higher education and the increase in institutional partnerships has caused UNICA to question the quality assurance mechanisms adopted by the different members of the region (Parkins, 2007). Indeed, UNICA views quality assurance and certification as playing an essential role in regulating educational institutions and in ensuring they are meeting the standards as well as protecting the cultural mores and values of the region.

The Second Special Meeting of the Standing Committee of Ministers Responsible for Education (SCME) (1997) had both a cultural and institutional mandate and vision. Culturally, it aimed to facilitate the 'Vision of the ideal Caribbean person' (CARICOM, 1997) or the 'neo-Caribbean citizen' (Jules, 2014). This individual is expected to: demonstrate that they are psychologically secure; value differences based on gender, ethnicity, religion and other forms of diversity as sources of strength and richness; be environmentally astute; be responsible and accountable to family and community; have a strong work ethic; be ingenious and entrepreneurial; have a conversant respect for the cultural heritage; exhibit multiple literacies, independent and critical thinking to the application of science and technology to problem-solving; and embrace the differences and similarities between females and males (CARICOM, 1997).

Institutionally, it established a Regional Accreditation Mechanism (RAM). The RAM was tasked with the execution of the policy, as detailed in the Revised Treaty of Chaguaramas. It was to allow for different categories of skilled nationals to move between CARICOM nations, as well as being closely linked to qualifications issued by National Accreditation Bodies (NABs). Thus, 'RAM has promoted quality assurance and program harmonization at the tertiary level, as well as established common standards and measures for accreditation and the mutual recognition of qualifications' (Jules, 2008: 290). Regional accreditation is seen as an essential part of the CARICOM Single Market and Economy (CSME) in order to ensure the facilitation of the regional skills regime through the recognition of credentials issued by higher education institutions in the region. 
In line with the mandates of the RAM, ten of the 15 CARICOM states have NABs, councils or presiding ministries of education, with the micro-states outsourcing accreditation to the United States and European nations. Hall and Cameron (2007) found that most of the English-speaking Caribbean nations had gained their independence by 1987, and also had established national colleges in order to develop their human capital. In a rush to gain credibility, institutions acted upon various measures to develop their programmes. Regional governments were frustrated with the diverging structures, and in 1988 they demanded that CARICOM nations develop a cohesive mechanism for equivalences, articulation, and accreditation. Additionally, educational leaders saw an opportunity to collaborate to address the growth of the educational landscape.

The 1990s was a period of higher education reform across the region. In response to the growing scrutiny that universities and colleges were facing, the UWI sought to create a network between Caribbean institutions (Nettleford, 2000). A collection of university and college officials, comprised of vice-chancellors, presidents, principals and chief executive officers, were assembled to establish the Association of Caribbean Tertiary Institutions (ACTI) in 1990 and was to become a formal network of higher education institutions (Nettleford, 2000; Hall and Cameron, 2007). Through two subcommittees, the ACTI was tasked with reviewing and creating mechanisms to ensure the equivalence, articulation and accreditation of an increasing number of programmes across higher education institutions.

\section{HORIZONTAL GOVERNANCE AND TRANSREGIONALISM}

In this section I discuss the rise of mature regionalism as a governance mechanism that steers different modes of coordination within integrative projects, or what has been identified as metagovernance. Until recently, several authors (see McBrian, 2001; Nicholas et al., 2001; Payne and Gamble, 1996; Girvan, 2001, 2011) have noted that Caribbean regional-ism has suffered from an implementation deficit. As such, the existing literature does not provide an adequate understanding for the study of a complex regime (or transregional regimes, as discussed below) which is amalgamated under a singular legal instrument that is regional in scope and embedded in the 'suitable structures of regional governance to manage an integrated economic space' (Lewis, 2006: 1), or what has been called 'mature regionalism' under the Rose Hall Declaration on Regional Governance and Integrated Development (CARICOM, 2003).

Mature regionalism can be seen as a machinery of governance or a horizontal mode of governance in that it preserves the basic character of CARICOM as a community of sovereign states. Furthermore, it focuses on deepening Caribbean economic relationships through structural changes (decision-making, management, implementation and enforceability), as opposed to widening Caribbean economic integration through 'open regionalism' through liberalizing economic integration whilst integrating the World Trade Organization regime rules into the Revised Treaty of Chaguaramas (Girvan, 2006; Jules, 2014; Odle, 2006; Pollard, 2012).

In doing so, mature regionalism, with its implicit expectations around steering, is now a metagovernance mechanism since it states that 'critical policy decisions of the Community taken by Heads of Government, or by other Organs of the Community, will have the force of law throughout the Region as a result of the operation of domestic legislation' (CARICOM, 2003: 1). Thus, it is expected that mature regionalism will still have a core functional element.

Within the framework of Caribbean regionalism, the move towards mature regionalism represents the rise of strategic coordination, which is a spatio-temporal horizon of metagovernance or meta-steering, ${ }^{4}$ and represents what Jessop (2000: 333) calls 'the strategic dimension of co- evolution of specific social forces' that gives rise to national policy spaces experiencing a 'geometry of insertion', where ideas and practices that were developed externally could be inserted in another place. The challenge with studying the shifting 'geometries of higher education space' (Robertson, 2010) in the Caribbean is that the existing literature does not lend itself to the easy use of such concepts, because 
Caribbean regional- ism is now intertwined with 'hemispherical regionalisms' (a generic term used to describe political and economic relations of regional blocs within the Western hemisphere). At the same time, the relationships between the different regional projects is unclear since both forms of regionalism are viewed as the 'path-shaping efforts of economic, political and other social forces to influence, steer or govern the nature and direction of their co-evolution' (Jessop, 2000: 333).

Within this context, state-led economic projects across different territorial scales in the 15 frontier markets of CARICOM were a response to Friedmanesque monetarism policies advanced through political projects known as 'Thatcherism' in the United Kingdom, and 'Reaganonomics' in the United States. These projects both promoted and reinforced globalization as a process and in turn gave birth to distinctive regional governance projects at new scales now dominated by a multiplicity of actors, institutions and reforms. We see here the movement from interregionalism, premised upon dialogues between representatives across different regions, and 'regulatory regionalism' (Jayasuriya and Robertson, 2010), where common standards are endorsed by national bureaucracies and adopted towards what I identify as 'transregionalism'. Transregionalism refers to the use of horizontal models of governance through 'external governance' as an 'attempt to bind neighboring countries into common policy frameworks [which] has been interpreted as an answer to this changed geopolitical landscape' (Lavenex and Wichmann, 2009: 84).

Transregionalism builds upon concepts of networked governance (see Lavenex, 2008; Lavenex and Wichmann, 2009) by singling out a 'set of formal and informal institutions that cut across and connect different geographical regions ... through a combination of regional, inter-regional and bilateral norms and forums' (Betts, 2011: 25). Where Jayasuriya (2003) speaks of 'embedded mercantilism' to characterize the export-orientated industrialization strategy of Southeast Asia, CARICOM's strategy of open regionalism in the form of production integration, and the governance mechanism of mature regionalism, can be seen as a new form of transregionalism in that these two regional projects are concurrently regulating educational governance activities. In essence, transregionalism provides a different articulation in identifying the 'relativization of scale' (Jessop, 2000) at the regional level since it draws attention to a 'more structural, institutionalist view on the expansion of the boundaries of regional integration and the continuities and disruptions between internal policies and their external dimension' (Lavenex, 2008: 939).

\section{TRANSREGIONALISM AND HIGHER EDUCATION}

Here, I follow Gibson's (2002: 2) logic that transregionalism 'is a structural attempt to combine a range of states within a coherent unified framework', particularly in this instance of region-to-region relations. ${ }^{5}$ CARICOM is a 'transregional regime' (Jules, 2008, 2013) in that it supports, legitimizes and institutionalizes international and regional patterns of supremacy, accumulation and exploitation by stipulating a set of implicit and explicit beliefs, standards, rules and procedures around which member states' expectations converge in education (Jules, 2012). Moreover, within the transregional space that CARICOM occupies and where governance instruments associated with mature regionalism exist, they are based on the establishment of frameworks (reducing transactional costs) and coordination of actors' expectations (improving quality and quantity of information available to states) as issues arise within any given policy space.

As a transregional regime, the regional space that higher education inhabits in the Caribbean is now defined by the functional or non- economic aspects of regionalism that are based on strategic coordination of metagovernance in order to engender a Caribbean region without barriers. This transregional space is a product of the post-Cold War period that has been shaped by the twin forces of the collapse of ideological pluralism (competing modules to engender national development) and the restructuring of regional projects from a common market based on free trade (old regionalism) towards trade liberalization and expanding membership. This has created the development of linkages with third states (open regionalism) under the Grand Anse Declaration (CARICOM, 1989) and now movement 
towards deeper regionalism through the Caribbean Single Market and Economy (mature regionalism).

The previous arguments of transregionalism can now be applied to the CSM that came into being in 2006, with 13 of CARICOM's now 15 member states actively participating in its regime instruments, namely the movement of goods regime, skills regime, services regime, capital regime, and the 'right to establish' regime - that is, CARICOM citizens may establish companies and business enterprises in any CARICOM nation and be treated as a local national. The CSM exhibits open regionalism by removing fiscal, legal, physical, technical and administrative barriers across CARICOM countries to allow for different regimes to function in a single large market and economic space. The different regimes of the CSM constitute a 'multinational integration framework' (Greene, 2005) that is 'multifunctional' (Girvan, 2005) by combining three distinct elements of transnational integration: (1) the retention of the common market that pools resources together in specific areas; (2) functional integration so that state sovereignty is non-negotiable with the possibility of federalist integration; and (3) supranationality in the form of shared sovereignty in the future. Even though the core components of the CSM are economic in scope, it has regional mechanisms and supporting institutions (such as the Caribbean Court of Justice and Regional Accreditation Mechanisms) as well as engaging national regulatory agencies (for example NABs and regional and national standard-setting bodies $)^{6}$ have been created to support it and designed to govern the coordination of 'functional space' within CARICOM.

Coupled with this, Caribbean integration now functions in spaces where CARICOM's members share membership in a multiplicity of regional blocs (discussed in the next section). Thus, Caribbean tertiary educational space is now a construct of 'regional political projects' (Jayasuriya, 2003) that are governed by the functional mechanisms of capital reproduction, regulation and regionalization (functional processes) in the interest of promoting regionalism (economic outcome) across different scales. In theory, the supporting institutions of the CSM are given legal jurisdiction under the Revised Treaty of Chaguaramas (CARICOM, 2001) and are now responsible for the educational governance activities and regulatory mechanism.

The movement towards transregionalism and transregional governance has resulted in forms of metagovernance where the Caribbean states still have a dominant role in educational governance (implementation), although the traditional educational governance activities (funding, provision, ownership and regulation) have now become regional in nature and scope. However, the mechanisms of educational governance have changed, and the educational outputs are wider and no longer national state-driven and -directed (these outputs are now just state-coordinated). Once the bastion of human resource development, the university and its institutions are now 'self-determining, self-regulatory and selfdirected' (Nettleford, 2000) producers and suppliers of services that are customer-driven, reviewer-ranked, and which no longer attend to national aspirations.

\section{THE CHANGING POLITICS AND GEOMETRY OF CARICOM REGIONALISM}

Historically, the Latin America and the Caribbean (LAC) region has used integrative political projects in the form of 'old regionalism' or 'closed regionalism' which is forwards-looking and is intended to spur economic development. Old regionalism promoted the manufacturing sector through import-substituting industrialization (ISI) - focusing on self-sufficiency and movement away from external dependency - whilst closing trade to those member states who were not part of the bloc. First and foremost, CARICOM has been designed to combine 'elements of "intergovernmentalism", (which recognizes the continuing importance of individual Member States in determining the path of the integration process), and elements of "neo-functionalism", (which is premised on the principle of shared sovereignty or the collective exercise of such sovereignty in specified areas)' (CARICOM, 2006: 14).

This combination of intergovernmentalism and neofunctionalism that now drives CARICOM's political project - and 
which differs from the European Union's idea of supranationalism - is based on the principles of proportionality and subsidiarity. On the one hand, proportionality means that the 'institutional arrangements devised for Community action shall not exceed what is necessary to achieve' (Lewis, 2006: 5) the actions specified in the Revised Treaty. On the other hand, subsidiarity, which forms the basic character of CARICOM as a community of sovereign states, 'asserts that regional action would not be pursued in cases where action by individual Member States is sufficient to achieve the specific goals of the Community' (ibid.).

Given the limitations of supra-nationalism as it currently exists within CARICOM and the resolution by CARICOM states that they are first and foremost sovereign states, metagovernance becomes relevant for explaining thinking behind the new governance mechanisms, since 'metagovernance instances can be established to coordinate the myriad subordinate forms of governance - this would re-introduce the principle of sovereignty or hierarchy that growing social complexity and globalization now rule out' (Jessop, 2004: 65).

The simultaneous rise of regional and hemispherical integrative projects are clearly reshaping regionalisms in Latin America and the Caribbean (LAC). When coupled with the retreat towards RTAs as a consequence of the changing nature of both globalizing and regionalizing processes, it could be argued that this is giving way to 'gated global' \{The Economist, 2013). Each of these dynamics is elaborated below.

In terms of the rise of regional integrative projects, today in LAC they range from customs unions that organize trade (for example, the Andean Community of Nations, CAN, formerly the Andean Pact; the Caribbean Free Trade Agreement, CARIFTA, now the Caribbean Community, CARICOM; the Latin American Integration Association, ALADI, formerly the Latin American Free Trade Association, ALALC; and the Southern Common Market, MERCOSUR), to complex currency and monetary unions (for example, the Caribbean Single Market of 2006; and the Eastern Caribbean Currency Union of the Organization of Eastern Caribbean States). The ways of conceptualizing regional political projects in the small (and micro) states and small island developing states (SIDS) of the Caribbean must take into account the 'existential threats' (Girvan, 2010) that challenge their economic vulnerability, food security and ecological fragility. CARICOM's integration project is facing its most demanding exogenous and endogenous pressures from competing hemispherical projects and regionalisms. Regional projects in LAC were never viewed as complementary systems - given their history and cultural outlooks - and thus there was never a push towards coordinating or standardizing these systems. As discussed below, this becomes more complex when one considers that several of the 15 members of CARICOM are also members of other sub-regional groupings or hemispherical groupings.

With the revision by CARICOM countries to the Original Treaty in 2001, provisions were made for the principle of 'open regionalism' or 'new regionalism' that calls for the removal of protectionism in the form of trade barriers that inhibit intraregional trade. However, the Caribbean model of new regionalism is now giving rise to transregionalism since it allow states to become part of several regional agreements at once, subsequently fostering 'the emergence of a multi-level decision-making structure: sub- state entities, states, regional forums, macro-regions and trans-regional spaces' (I Vidal, 2008: 43). In CARICOM, open regionalism (in the form of production integration: 'organisation of integrated regional industrial complexes from raw materials to finished Products', Girvan, 2006: 8) as an economic process is concerned with widening the economic arrangements through the CARICOM Single Market and Economy to allow for the creation and embedding of different regimes (movement of skills, labour, capital services and the right to establishment).

However, it was not until 2010 that regional leaders took notice of the perceived new threats to integration projects when Guyana and Suriname joined the Union of South American Nations (UNASUR), which combined two existing customs unions, the Southern Common Market (MERCOSUR) and the Andean Community of Nations 
(CAN). In 2011,13 CARICOM states ${ }^{7}$ were part of the contingent of 33 countries that signed the Declaration of Caracas, creating the Community of Latin American and Caribbean States (CELAC) that is now focused on deeper integration. In 2012 Haiti, Suriname and Saint Lucia ${ }^{8}$ acceded to the Bolivarian Alliance for the Peoples of Our America (ALBA) (see Muhr, Chapter 12 in this volume), of which CARICOM members Antigua and Barbuda, Dominica and Saint Vincent and the Grenadines ${ }^{9}$ were already members.

Additionally, CARICOM members belong to other regional zones aimed at promoting economic cooperation; namely the 25-member grouping of the Association of Caribbean States and the 28-country Sistema Economico LatinAmerican y del Caribe (SELA, the Latin American and the Caribbean Economic System). The emergence of transregionalism, where countries are members of the same regional blocs within the same geopolitical and geohemispherical spaces, raises questions about the 'compatibility or incompatibility of different governance regimes and their implications for the overall unity' (Jessop, 2004).

It is thus now possible to see regional and hemispherical projects or regionalism across different spaces and scales, and a retreat towards RTAs in light of the slowing of globalization and economic liberalization, as related to what has been called the rise of 'gated globalization' (The Economist, 2013). This implies the need for new ways to theorize the study of regional levels. Within this 'gated global' we are also seeing the 'gated regional', which is even less bureaucratic than the previous era and whose defining feature is openness at the regional level in the form of protection- ism against non-regional members. In fact, an era of open regionalism now exists side-by-side with the mature regionalism that has been built as a governance mechanism to facilitate the implementation of CSM-related instruments.

In the post-2008 financial crisis era, the new orthodoxy of state capitalism has tended to lead to a retreat to hidden protections that regional trading agreements can offer countries. Whilst historically RTAs have been seen as offering an alternative to globalization by conferring full entry into the global knowledge economy, today RTAs facilitate the expansion of education into a tradable commodity whilst at the same time protecting and promoting national interests (Jules, 2014). Such a retreat towards RTAs has significant consequences for Caribbean integration, since these institutions fund a significant part of specialized projects that reinforce the core tendencies of regionalism.

\section{CONCLUDING THOUGHTS}

Transregionalism is one outcome of the reseating of higher education governance and its changing geometry. As a result, the CHES now promotes its own governance mechanisms in the form of educational cooperation whilst at the same time being subjected to external regulation to ensure programmes are competitive. The changing nature of regionalism in the Caribbean, with the proliferation of new political projects regionally and hemispherically, means that higher education regulations now have to be standardized, coordinated and regionalized. Both endogenous and endogenous forces are penetrating tertiary education in the Caribbean in relation to the nature, scope, function, space and governance of the sector. Caribbean higher education now exists in a spatio-temporal horizon of metagovernance that is driven by functional cooperation and governed by mature regionalism. Here, mature regionalism can be seen as a new form of metagovernance, which is the collibration of different governance mechanisms, on the one hand, and the governance of the different relationship among these different modes of coordination (Jessop, 2000) on the other. Mature regionalism, therefore, has given birth to a new set of institutions that are now responsible for the coordination of higher education activities.

For CARICOM, the new merging landscape of regional and hemi- spherical projects is a minefield that is likely to have a substantive impact upon intra-state relations and the overall governance of tertiary education. Jayasuriya and Robertson (2010) suggest that regulatory regionalism is distinctive in that it does not impose a regulatory template but 
fosters relationships and connections that transform the geographical scales that it occupies, accommodates diverse patterns of national governance, and functions as a set of metaconstitutional standards. This chapter has attempted to focus on the soft forms of the governance processes and mechanism of political projects of regulatory regionalism. In the Caribbean, the ideas of coordination, collaboration and commonality that can be seen as the outcome of regulatory regionalism have always existed, however, their degree and intensity has varied since the establishment of CARICOM. In fact, the ways in which higher education is governed and regulated across different scales has not changed. It is the intensity of the processes that continues the metamorphosis of the region from immature to mature as new demands are placed upon the regulatory system. While the mechanisms (cooperation and collaboration) of regionalization have remained consistent, regionalism has been morphing, expanding and contracting across the Caribbean. In fact, a distinctive feature of regionalism in the Caribbean today is that several countries are members of different regional blocs, but they suffer from 'political resistance [due to] national circumstances and interests, absence of supranationality in governance and administrative and institutional deficiencies at the national level' (Bishop et al., 2011: 20). Given that memberships are intertwined across different regional blocs, it is particularly difficult to speak of Caribbean or Latin American integration, but instead it makes more sense to talk of a 'panregional' or 'pan-hemispherical' integration mélange that combines the political, social, economic and ideological aspirations of these countries in a shifting set of social and spatial relations.

\section{NOTES}

1. CARICOM's current members are Antigua and Barbuda, Barbados, Belize, Dominica, Grenada, Guyana, Haiti, Jamaica, Montserrat, Saint Kitts and Nevis, Saint Lucia, Saint Vincent and the Grenadines, Suriname, and Trinidad and Tobago. However, the Bahamas and Haiti are not members of the Caribbean Single Mariiet and Economy.

2. My use of 'transregional' in this chapter has also been described as 'interregionalism' when contextualizing the process of the Asia-Europe Meeting (see Aggarwal and Fogarty, 2004; Dent, 2003; Kim, 2003; Song, 2007).

3. Functional cooperation is one of the four pillars (the others being economic integration, foreign policy coordination and, added in 2007, security) of Caribbean integration as enshrined in the Revised Treaty of Chaguaramas.

4. Jessop (2003) reformulated his conceptualizations of meta-steering as metagovernance.

5. Historically transregionalism would be applied to EU-Latin America and Caribbean (EU-LAC) summit relations, but in the changing landscape of Caribbean and Latin American relations transregionalism can now be expanded to account not only for North-South relations but also South-South relations. Also, since 1981, CARICOM has been engaged in transregionalism relations, when the Organization of Eastern Caribbean States (OECS), as a sub-regional entity within CARICOM, was created and all of the OECS states acceded to CARICOM. Today, the seven full members (Antigua and Barbuda, Dominica, Grenada, Montserrat, Saint Kitts and Nevis, Saint Lucia, and Saint Vincent and the Grenadines) are still members of CARICOM, while Anguilla (a full member of CARICOM) and the British Virgin Islands are associate members of the OECS.

6. Examples of such regional bodies are such as the Caribbean Regional Organization on Standards and Quality (CROSQ) that was established under Article 67 of the Revised Treaty of Chaguaramas (CARICOM, 2001).

7. Members of CELAC: Antigua and Barbuda, Bahamas, Barbados, Belize, Dominica, Grenada, Guyana, Jamaica, Saint Lucia, Saint Kitts and Nevis, Saint Vincent and the Grenadines, Suriname, and Trinidad and Tobago. 
8. Haiti, Suriname and Saint Lucia were admitted to ALBA in 2012.

9. Dominica joined in 2008, and Antigua and Barbuda, and Saint Vincent and the Grenadines, joined in 2009.

\section{REFERENCES}

Aggarwal, V. and E.A. Fogarty (2004), Between Regionalism and Globalization: European Union Interregional Trade Strategies. In V. Aggarwal and E.A. Fogarty (eds), EU Trade Strategies: Between Regionalism and Globalism. London, U K and New York, USA: Palgrave, pp. 1-40.

Betts, Alexander (2011), The Global Governance of Migration and the Role of Transregionalism. In Rahel Kunz, Sandra Lavenex and Marion Panizzon (eds), Multilayered Migration Governance: The Promise of Partnership. New York: Routledge, pp. 23-45.

Bishop, M., N. Girvan, T. Shaw, S. Mike, R. Kirton, M. Scobie, D. Mohammed and M. Anatol (2011), Caribbean Regional Integration. A Report by the UWI Institute of International Relations, http://cms2.caricom.org/documents/9774-iir regionalintegrationreportfinal.pdf (accessed 25 April 2016).

CARICOM (1989), Grand Anse Declaration and Work Programme for the Advancement of the Integration Movement, July 1989. Grand Anse, Granada.

CARICOM (1997), Creative and Productive Citizens for the Twenty-first Century. Paper presented at the Eighteenth Meeting of the Conference of Heads of Government of the Caribbean Community, Montego Bay, Jamaica. http://www. caricom.org/jsp/communications/meetings_statements/citizens_2I_century.jsp?me nu=communications.

CARICOM (2001), Revised Treaty of Chaguaramas. http://www.sice.oas.org/trade/caricom/caricind.asp.

CARICOM (2003), The Rose Hall Declaration on Regional Governance and Integrated Development. Georgetovra: CARICOM. http://www.caricom.org/ jsp/commimications/meetings_statements/rose_haJl_declaration.jsp?menu=communications.

CARICOM (2006), Report of the Technical Working Group on the Governance of the Caribbean Community. Republic of Trinidad and Tobago: CARICOM. http://archive.caricom.org/jsp/community/twg_govemance_report.pdf

Dale, R. (2005), Globalisation, Knowledge Economy and Comparative Education. Comparative Education, 41(2), 117-149.

Dent, C.M. (2003), From Inter-regionalism to Transregionalism? Future Challenges for ASEM. Asia Europe Journal, 1(2), 223-235.

The Economist (2013), Gated Globe. 12 October, http://www.economist.com/news/ special-report/21587384forward-march-globalisation-has-paused-financial-cris is-giving-way (accessed 25 April 2016).

Girvan, N. (2001), Reinterpreting the Caribbean. In F. Lindahl and B. Meeks (eds), New Caribbean Thought. Kingston: University of the West of Indies Press. http://www.normangirvan.info/wp- 
content/uploads/2007/09/reinterpreting-the- caribbean-2001.pdf (accessed 25 April 2016).

Girvan, N. (2005), Whither CSME? Journal of Caribbean International Relations, 1(April), 13-32.

Girvan, N. (2006), Production Integration: A Critical Perspective. In K. Hall and D. Benn (eds), Production Integration in CARICOM; From Theory to Action. Kingston: Ian Randle Publications, pp. 8-29.

littp://www.normangirvan. info/wp-content/uploads/2007/09/production-integration-a-critical-perspective- jan06.pdf.

Girvan, N. (2010), Are Caribbean Countries Facing Existential Threats? http:// www.normangirvan.info/wpcontent/uploads/2010/11/existential-threats.pdf (accessed 25 April 2016).

Girvan, N. (2011), Is ALBA a New Model of Integration? Reflections on the CARICOM Experience. International Journal of Cuban Studies, 3(2-3),157-180.

Greene, E. (2005), Free Movement of Persons: The Vision and the Reality. CARICOM Directors of Government Information Services, 16-17 March.

Hall, K. and R. Cameron (eds) (2007), Higher Education Caribbean Perspective. Kingston: Ian Randle.

I Vidal, L.L. (2008), The Theoretical Contribution of the Study of Regionalism and Interregionalism in the ASEM Process. In L.H. Yeo and L.L. I Vidal (eds), Regionalism and Interregionalism in the ASEM Context - Current Dynamics and Theoretical Approaches. Barcelona: CIDOB, pp. 31-70.

Jayasmiya, K. (2003), Introduction: Governing the Asia Pacific - Beyond the 'New Regionalism'. Third World Quarterly, 24(2), 199-215.

Jayasuriya, K. and S.L. Robertson (2010), Regulatory Regionalism and the Governance of Higher Education. Globalisation, Societies and Education, 8(1), 1-6.

Jessop, B. (2000), The Crisis of the National Spatio-Temporal Fix and the Tendential Ecological Dominance of Globalizing Capitalism. International Journal of Urban and Regional Research, 24(2), 323-360.

Jessop, B. (2003), Governance and Metagovernance: On Reflexivity, Requisite Variety, and Requisite Irony. In H.P. Bang (ed.). Governance, as Social and Political Communication. Manchester: Manchester University Press, pp. 142-172.

Jessop, B. (2004), Multi-level Governance and Multi-level Metagovernance Changes in the European Union as Integral Moments in the Transformation and Reorientation of Contemporary Statehood. In I. Bache and M. Flinders (eds), Multi-Level Governance. Oxford: Oxford University Press, pp. 49-74.

Jules, TD. (2008), Re/thinking Harmonization in the Commonwealth Caribbean. Audiences, Actors, Interests, and Educational Policy Formation. Doctoral thesis. Teachers' College Columbia, New York.

Jules, TD. (2012), Re-reading the Anamorphosis of Educational Fragility, Vulnerability, and Strength in Small States. Current Issues in Comparative and International Education, 1(15), 5-13. 
Jules, TD. (2013), Ideological Pluralism and Revisionism in Small (and Micro) States: The Erection of the Caribbean Education Policy Space. Globalisation, Societies and Education, 11(2), 37-41.

Jules, TD. (2014), Trans-regional Regimes and Globalization in Education: Constructing the Neo-Caribbean Citizen. In I. Silova and D. Hobson (eds). Globalizing Minds: Rhetoric and Realities in International Schools. Chapel Hill, NC: Information Age, pp. 249-275.

Kim, J. (2003), Sub-regionalism, Regionalism, Trans-regionalism: Implications for Economic Integration and International Trade Policies. Asia Europe Journal, 1(2), 183-196. Lavenex, S. (2008), A Governance Perspective on the European Neighbourhood Policy: Integration Beyond Conditionality? Journal of European Public Policy, 15(6), 938-955.

Lavenex, S. and N. Wichmann (2009), The External Governance of EU Internal Security. Journal of European Integration, 31(1), 83-102.

Lewis, VA. (2006), Managing Mature Regionalism: Regional Governance in the Caribbean Community. Report of the Technical Group on Governance Appointed by CARICOM Heads of Government. October. CARICOM.

McBrian, H. (2001), Open Regionalism: CARICOM Integration and Trade Links. In V. Buhner-Thomas (ed.). Regional Integration in Latin America and the Caribbean: The Political Economy of Open Regionalism. London: ILAS London, pp. 275-294.

Nettleford, R. (2000), Contrasting Problems Facing Universities in the Developed and Developing Worlds: The Same Difference. In Glenford D. Howe (ed.), Higher Education in the Caribbean: Past, Present, and Future Directions. Kingston: University of the West Indies Press, pp. 24-44.

Nicholls, S., P. Samuel, R Colthrust and E. Boodoo (2001), Open Regionalism and Institutional Developments among the Smaller Integration Schism of CARICOM, the Andean Community and the Central America Common Market. In V. Buhner-Thomas (ed.), Regional Integration in Latin America and the Caribbean: The Political Economy of Open Regionalism, London: ILAS, pp. 141-164.

Odle, M. (2006), Production Integration in the CSME: A Business Perspective. In D. Benn and K.O. Hall (eds). Production Integration in CARICOM: From Theory to Action, Kingston: Ian Randle Publications, pp. 30-55.

Parkins, L. (2007), Building Bridges of Collaboration in Higher Education: The UNICA Situation. In Kenneth O. Hall and Rose Marie Cameron (eds), Higher Education: Caribbean Perspectives. Kingston: Ian Randle Publishers, pp. 166-173.

Payne, A. and A. Gamble (1996), Introduction: The Political Economy of Regionalism and World Order. In A. Gamble and A. Payne (eds). Regionalism and World Order, London, UK and New York, USA: Palgrave, pp. 1-20.

Pollard, D.D. (2012), Interrelationships between Community and National Competition Rules. In K. Hall and M. Chuck-A-Sang (eds). Managing Mature Regionalism. Bloomington, NY: Trafford Publishing, pp. 78-197.

Robertson, S. (2010), The EU, 'Regulatory State Regionalism' and New Modes of Higher Education Governance. Globalisation, Societies and Education, 8(1), 23-37. 
Second Special Meeting SCME (1997), Report of the Second Special Meeting of the Standing Committee of Ministers Responsible for Education (REP.97/2/69 SCME [Spec.]). May Bridgetown, Barbados: CARICOM.

Song, W (2007), Regionalisation, Inter-regional Cooperation and Global Governance. Asia Europe Journal, 5(1), 67-82. 